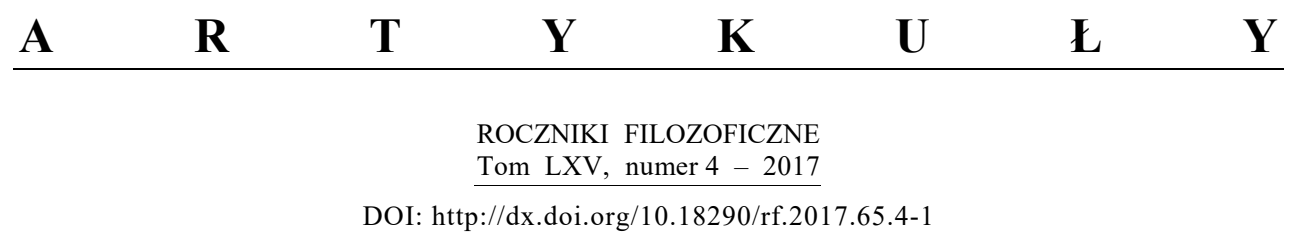

WŁODZIMIERZ GALEWICZ

\title{
CZY WARTOŚĆ ŻYCIA WZRASTA WOBEC BLISKIEJ ŚMIERCI?*
}

Przemysł farmaceutyczny oferuje coraz to nowe leki, które mają przedłużać życie osób cierpiących na nieuleczalne choroby. Innowacyjne terapie są często w jakimś stopniu skuteczniejsze, ale też (w co najmniej takim samym stopniu) droższe. Upoważnieni decydenci reprezentujący społeczeństwo muszą zatem rozstrzygać, które $\mathrm{z}$ nich będą finansowane ze środków publicznych. Jednym z głównych kryteriów, na których podstawie podejmuje się takie decyzje, jest stosunek dodatkowych kosztów, związanych $\mathrm{z}$ nową terapią, do czerpanych $\mathrm{z}$ niej dodatkowych korzyści. Dodatkowe korzyści, wynikające z nowych leków dla osób śmiertelnie chorych, wydają się jednak często niezbyt wielkie $\mathrm{w}$ porównaniu $\mathrm{z}$ ich zawrotnymi dodatkowymi kosztami. Rodzi się zatem wątpliwość, czy refundacja tych leków, do której opinia społeczna skądinąd na ogół się skłania, daje się pogodzić $\mathrm{z}$ równie powszechnie akceptowaną zasadą ekonomicznej efektywności. Pewną próbą uzgodnienia tych postaw byłoby przyjęcie, że z pozoru niewielkie korzyści, przysparzane osobom zbliżającym się do śmierci — jak marginalne zwiększenie długości ich życia lub nieznaczne podniesienie jego jakości w rzeczywistości mają większą wartość, ponieważ życie tych osób trzeba cenić wyżej. W niniejszym artykule zastanawiam się nad tym, czy ta koncepcja jest do utrzymania - czy wartość życia wzrasta wobec bliskiej śmierci.

Prof. dr hab. WŁodzIMIERz GALEwICZ - kierownik Zakładu Badań nad Etyką Zawodową, Uniwersytet Jagielloński, Wydział Filozoficzny, Instytut Filozofii; adres do korespondencji: ul. Grodzka 52, 31-044 Kraków; e-mail: galewicz@if.uj.edu.pl

* Poniższy artykuł jest związany z moim projektem badawczym „Sprawiedliwość w opiece zdrowotnej”, finansowanym przez NCN w ramach konkursu Maestro 4 (nr 2013/08/A/HS1/00079). 
Przedmiotem tego artykułu będzie jedno z pytań, nasuwających się w odniesieniu do wartości życia. Pytając o wartość życia, możemy mieć na myśli różne sprawy, zależnie od tego, co rozumiemy przez życie i — odpowiednio do tego - jak rozumiemy wartość. Gdy chodzi o to pierwsze, to mówiąc o życiu po prostu będę miał tutaj na myśli zawsze życie ludzkie, pozostawiając $\mathrm{w}$ zawieszeniu takie graniczne wątpliwości, jak chociażby ta, czy życie człowieka w trwałym stanie wegetatywnym jest jeszcze życiem ludzkim, czy też nie. Nawet jednak wartość życia bezspornie ludzkiego ma jeszcze dwa istotnie różne, choć nieraz mieszane ze sobą znaczenia. Ich różnicę możemy uchwycić, biorąc pod uwagę pewne swoiste stanowisko w sprawie etycznej godziwości eutanazji. Jego zwolennicy podkreślają zwykle, że ludzkie życie ma pewną nienaruszalną wartość, nazywaną także godnością, a czasem świętością, ze względu na którą powinno się mu okazywać należny szacunek. Co trzeba robić, a czego nie robić, aby traktować ludzkie życie z należnym szcunkiem, w tej sprawie możliwe są różne poglądy, lecz zgodnie z przywoływanym tu zapatrywaniem poza dyskusją jest przynajmniej to, że nie należy go unicestwiać lub niszczyć, aktywnie przyczyniać się do jego zakończenia. Nie wolno tego czynić nawet wtedy, gdy to życie przestaje być dla jakiegoś człowieka darem czy też dobrem, a staje się dlań nieznośnym brzemieniem. Nawet bowiem takie życie, które jest dla człowieka przytłaczającym ciężarem, ma wartość nienaruszalną; zgodnie z nieco paradoksalną tezą rzeczników omawianego poglądu - i właśnie ta myśl jest dla nich swoista - ma ono nadal wartość nienaruszalną, choć nie ma już wartości dobra dla tego, kto żyje.

Pozorny paradoks ma oczywiście proste rozwiązanie, jeżeli zwrócimy uwagę, że o „wartości” mówi się tutaj w dwóch różnych znaczeniach: raz w tym, które określa się czasem jako znaczenie kantowskie i w którym wartość jest równoznaczna z godnością — cechą czegoś, co należy szanować a drugim razem w znaczeniu, w którym wartość oznacza raczej cechę dobra — czegoś, co warto wybrać, do czego warto dążyć, czego warto pragnąć ${ }^{1}$. Przedmiotem mojej uwagi będzie w dalszym ciągu wartość życia rozumiana zgodnie z tym drugim, teleologicznym pojęciem wartości, a zatem wartość życia jako pewnego dobra, stanowiącego cel godny wyboru.

Teleologiczne pojęcie wartości życia może niekiedy dotyczyć wartości życia jako pewnej diachronicznej całości, np. ujmowanej z perspektywy

\footnotetext{
${ }^{1}$ Por. BRADLEY 2006
} 
kogoś, kto zbliża się do jej kresu. Umierający Ludwig Wittgenstein miał ponoć powiedzieć do swojego lekarza, a zarazem jednego z przyjaciół: „Powiedz im, że miałem wspaniałe życie”. Kiedy indziej jednak ocena wartości życia będzie się odnosić do pewnej jego części, szczególnie tej przyszłej. Zastanawiając się nad wartością życia jakiejś osoby, mamy więc wówczas na myśli życie, które ta osoba może jeszcze przeżyć. Możemy też porównywać rozmaite dalsze przebiegi czy też scenariusze życia, możliwe dla danej osoby, i oceniać ich względną wartość.

Wartość pewnej części czy też „porcji” życia, którą jakaś osoba może jeszcze przeżyć, będzie oczywiście zależeć od jego długości — od tego, ile dalszych lat czy też miesięcy owa osoba ma jeszcze przed sobą lub miałaby przed sobą w danym scenariuszu. Jak jednak dobrze wiadomo, jeden rok lub miesiąc życia rzadko jest równy drugiemu. Wartość tych przyszłych odcinków życia, które możemy poddawać ocenie, będzie zatem zależna nie tylko od ich czasowej długości. Będzie też oczywiście zależeć od tego, co zwykle nazywa się jakością życia. Mniej jasna — i dlatego właśnie godna rozpatrzenia — jest jednak ewentualna zależność wartości jakiegoś odcinka życia od pewnej innej, niejakościowej cechy, którą można by nazwać jego czasową pozycję. Mówiąc o czasowej pozycji, mam tutaj na myśli miejsce, jakie pewien odcinek życia - np. rok czy też miesiąc - zajmuje w całym jego przebiegu. To miejsce może być jednak określane jakby z dwóch stron: albo od strony lat lub miesięcy już przeżytych przez daną osobę, albo od strony lat lub miesięcy, które ta osoba jeszcze może przeżyć. Oba te czasowe aspekty ocenianej części życia, a więc zarówno jej pozycję ze względu na przeszłość, jak jej pozycję ze względu na przyszłość, możemy brać pod uwagę, kiedy szukamy innych cech pewnego odcinka dalszego życia, oprócz jego długości i jego jakości, które mogą wywierać wpływ na jego wartość. Pytanie, jaką wartość ma pewien odcinek życia, nie utożsamia się naturalnie z pytaniem, ile warto za niego zapłacić. W praktyce jednak te dwa pytania, mimo ich całej kategorialnej różności, niejednokrotnie idą z sobą w parze.

Weźmy pod uwagę następujący typowy przypadek. 70-letni pacjent, pan $X$, cierpi na nieuleczalną formę raka. Obecnie znajduje się już w dość późnej fazie choroby, tak że leczony za pomocą standardowych środków przeżyje jeszcze zapewne około dwóch lat. Na rynku leków pojawia się jednak nowy specyfik, innowacyjna chemioterapia, która według przeprowadzonych badań klinicznych przedłuża życie pacjentów cierpiących na tę formę raka i znajdujących się w tej jego fazie, statystycznie biorąc, o dalsze sześć miesięcy. Niestety, rewelacyjny lek jest bardzo drogi. Pełna kuracja z jego uży- 
ciem kosztuje o 100000 więcej niż kuracja za pomocą najdroższego z leków dotąd stosowanych. Czy korzyść, którą pan X odniesie dzięki tej terapii, a zatem większa długość jego życia, jest warta tego dodatkowego wydatku? Zależy to oczywiście jeszcze od wartości tej dodatkowej korzyści. Jaką więc wartość miałoby dla pana X-a — dla jego bliskich, dla społeczeństwa czy w ogóle dla świata - to darowane mu pół roku życia?

Jest jasne, że aby ustalić tę wartość, musimy zainteresować się najpierw jakością, którą - według rozsądnych prognoz — posiadałoby życie pacjenta $\mathrm{w}$ tym darowanym mu czasie: czy przebiegałoby ono w cierpieniu lub otępieniu, czy też w sposób względnie normalny. Oprócz tego oczywistego pytania możemy jednak postawić dwa inne. Po pierwsze, możemy zapytać o wpływ, jaki na wartość tych dodatkowych sześciu miesięcy życia, uzyskiwanych przez pacjenta dzięki nowej terapii, miałaby ich pozycja ze względu na przeszłość: czy owa wartość nie byłaby większa, gdyby ten dodatkowy odcinek czasu otrzymywał nie człowiek, który bądź co bądź ma już za sobą 70 lat życia, lecz ktoś młodszy, kto przeżył dopiero 30 lub 40 lat? Po drugie, możemy również zastanawiać się, czy wartość pozyskiwanych przez pacjenta szesciu miesięcy życia nie zależałaby od ich pozycji ze względu na przyszłość - czy nie byłaby ona mniejsza, gdyby to dodatkowe dobro, otrzymane przez pacjenta $\mathrm{w}$ darze od medycyny, podarowano nie człowiekowi, który inaczej umrze za dwa lata, lecz komuś, kogo od statystycznie spodziewanej śmierci dzieli jeszcze jakiś bezpieczniejszy dystans, np. 12 lat?

Ogólnie mówiąc, aby ustalić, jaki wpływ na wartość pewnego odcinka życia wywiera jego czasowa pozycja, trzeba by rozważyć dwie kwestie. Jedna $\mathrm{z}$ nich wiąże się z szerszą dyskusją, toczącą się w etyce medycznej wokół tzw. dyskryminacji pacjentów ze względu na wiek i w najprostszym sformułowaniu brzmi: czy wartość życia maleje z wiekiem? Tą pierwszą kwestią, wymagającą osobnej analizy, nie będę się jednak zajmował w dalszym ciągu tego artykułu i ograniczę się tylko do drugiej, sformułowanej już w jego tytule: czy wartość życia wzrasta wobec bliskiej śmierci?

Podejmowana kwestia nie jest tylko ciekawą aporią z zakresu filozoficznej teorii wartości. Ma także bezpośredni związek z jak najbardziej praktycznym problemem opieki medycznej, którym jest problem właściwej dystrybucji czy też alokacji zasobów zdrowotnych. 
Przez zasoby zdrowotne rozumie się różnego rodzaju środki czy też dobra wykorzystywane w służbie zdrowia: od środków finansowych, czyli po prostu pieniędzy, poprzez zasoby rzeczowe, jak lekarstwa lub sprzęty medyczne, aż po zasoby osobowe, jak choćby siły i godziny pracy lekarzy, pielęgniarek i innych członków personelu medycznego. Dystrybucją lub alokacją tych różnorakich zasobów nazywa się ich podział pomiędzy różne medyczne cele, rodzaje świadczeń czy też grupy osób. Pytając o „właściwy” sposób ich dystrybucji czy też alokacji, zadajemy oczywiście pytanie jawnie normatywne, ponieważ chcemy ustalić, jak te zasoby powinno się dzielić. Nietrudno przewidzieć, że różne odpowiedzi, których udziela się na to pytanie - czy to $\mathrm{w}$ jego ujęciu ogólnym, czy w zastosowaniu do rozmaitych kwestii szczegółowych - będą ostatecznie zależeć od takiej lub innej teorii czy też przynajmniej orientacji lub postawy zajmowanej wobec powinności etycznych. Inaczej ten „właściwy”, „słuszny” lub „racjonalny” sposób alokacji zasobów zdrowotnych będzie określany przez zwolenników tej czy innej formy utylitaryzmu, sprowadzających jego racjonalność do efektywności, inaczej zaś przez przedstawicieli pewnej teorii deontologicznej, zabiegających także o jego równość czy też sprawiedliwość. Aby jednak nie podchodzić zbyt defetystycznie do możliwości porozumienia się tych rozbieżnych stanowisk, możemy przyjąć, że wszystkie one zgodzą się ostatecznie na pewną rudymentarną teorię etyczną, którą można by nazwać minimalnym konsekwencjalizmem. Tym mianem obejmuję tutaj każde stanowisko, w którym przynajmniej jako jedną $\mathrm{z}$ obowiązujących norm naczelnych przyjmuje się zasadę maksymalizacji dobra. Zgodnie $\mathrm{z}$ tą zasadą, która w klasycznym konsekwencjalizmie będzie zasadą jedyną, a w innych teoriach być może tylko jedną z wielu, powinniśmy troszczyć się o to, aby przez nasze działania urzeczywistniać w świecie jak najwięcej dobra. Ta być może nie wszechwładna, ale powszechna zasada etyczna odnosi się do różnych działań i wyborów, między innymi jednak również i do tych, których dokonuje się w zakresie opieki zdrowotnej. Także i te działania, a w szczególności decyzje dotyczące rozdziału zasobów zdrowotnych, powinny zatem być dokonywane w taki sposób, aby wynikało z nich jak najwięcej korzyści, z tym może tylko istotnym dodatkiem, że ich nadrzędnym lub właściwym celem jest maksymalizacja wartości korzyści zdrowotnych.

Jeżeli jednak do nadrzędnych normatywnych podstaw, na których mamy się oprzeć w dystrybucji zasobów zdrowotnych, należy zasada maksymalizacji korzyści związanych ze zdrowiem, to oczywiście powstaje pytanie, w jaki sposób w ogóle wyodrębnić tego rodzaju rodzaju korzyści, wynika- 
jące $\mathrm{z}$ różnych decyzji medycznych, a także jak ocenić lub zmierzyć ich wartość. W zastosowaniu do świadczeń medycznych, które mają ratować przed przedwczesną śmiercią, prostą miarą wielkości wynikających z nich korzyści zdrowotnych byłaby liczba uzyskiwanych dzięki nim dodatkowych lat życia. Celem jednak większości interwencji medycznych jest nie tylko przedłużanie życia, lecz także — a nieraz wyłącznie - jego polepszanie, podnoszenie jego jakości. A jak już wiemy, wartość pewnego odcinka życia, pozyskiwanego dzięki jakiejś terapii, zależy nie tylko od jego długości czyli od owej liczby składających się nań dodatkowych lat czy też miesięcy - ale także od jego jakości. Aby uwzględnić to drugie kryterium wartości, stosowane przy ocenie korzyści zdrowotnych, prostą miarę liczby lat życia zastąpiono bardziej złożoną miarą „liczby lat życia skorygowanej o ich jakość" (quality adjusted life years — QALY). Skoro jednak powodem do takiej „korekty” jest wzgląd na zależność, jaka zachodzi między wartością pewnego odcinka życia i jego jakością, to i ta standardowa miara może być jeszcze traktowana jako niewystarczająca. Jak bowiem stwierdziliśmy, wartość pewnego odcinka życia, pozyskiwanego dzięki medycynie, może zależeć nie tylko od jego długości i jego jakości, ale także od czasowej pozycji, którą on zajmuje. Być może więc jako dokładniejszą miarę wielkości korzyści zdrowotnych należałoby przyjąć nie tyle „liczbę lat życia skorygowaną o ich jakość”, ile „liczbę lat życia skorygowaną o ich wartość”, oceniając tę ostatnią zarówno poprzez kryterium jakości, jak i poprzez kryterium pozycji.

Standardową metodę oceny korzyści zdrowotnych stosuje się między innymi innymi przy decyzjach dotyczących refundacji nowych sposobów terapii. Nowa terapia, wynaleziona przez przemysł medyczny, zostaje włączona do koszyka świadczeń refundowanych, jeżeli z medycznego, a zarazem ekonomicznego punktu widzenia istotnie góruje nad terapią tradycyjną, tzn. jeżeli osiągane dzięki niej dodatkowe korzyści zdrowotne pozostają w odpowiedniej proporcji do związanych z nią dodatkowych kosztów. Jaki stosunek dodatkowych kosztów, wiążących się z nową terapią, do wynikających z niej dodatkowych korzyści można uznać za akceptowalny, to siłą rzeczy zależy od zasobu środków, które w danym kraju przeznacza się na utrzymywanie i rozwijanie systemu opieki zdrowotnej.

Światowa Organizacja Zdrowia (WHO) ${ }^{2}$ zaleciła, aby w ocenie kosztowej efektywności procedur medycznych posługiwać się pewną uniwersalną, ale giętką miarą, którą stanowi wielkość produktu krajowego brutto przypa-

\footnotetext{
${ }^{2}$ Por. World Health Organization, „Cost effectiveness and strategic planning (WHO-CHOICE)”, dostęp 25.10.2017, http://www.who.int/choice/en/
} 
dająca na jednego mieszkańca: jeżeli dodatkowy koszt uzyskania dzięki jakiejś procedurze jednego dodatkowego roku życia o nieuszczuplonej jakości jest równy trzykrotności tej miary, procedura ma być oceniana jako dostatecznie efektywna; jeżeli mniejszy — jako bardzo efektywna; jeżeli większy - jako nieefektywna. Polskie prawo medyczne dość ściśle stosuje się do tego zalecenia. W art. 12 pkt 13 ustawy z dnia 12 maja 2011 r. o refundacji leków, środków spożywczych specjalnego przeznaczenia żywieniowego oraz wyrobów medycznych ${ }^{3}$ czytamy, że „Minister właściwy do spraw zdrowia, mając na uwadze uzyskanie jak największych efektów zdrowotnych w ramach dostępnych środków publicznych, wydaje decyzję administracyjną o objęciu refundacją i ustaleniu urzędowej ceny zbytu", przy uwzględnieniu szeregu wyszczególnionych kryteriów, w tym między innymi „wysokości progu kosztu uzyskania dodatkowego roku życia skorygowanego o jakość, ustalonego w wysokości trzykrotności Produktu Krajowego Brutto na jednego mieszkańca”. Aktualną wysokość progu kosztu uzyskania jednego QALY, obowiązującą od pewnej daty, ustala Agencja Oceny Technologii Medycznych i Taryfikacji (AOTMiT), biorąc pod uwagę przywołane przepisy oraz dane Głównego Urzędu Statystycznego w sprawie szacunków wartości produktu krajowego brutto na jednego mieszkańca w okresie poprzedzającym tę datę. Tak np. w Komunikacie Prezesa AOTMiT z listopada 2015 r. czytamy, że skoro „wartość produktu krajowego brutto na jednego mieszkańca w latach 2011-2013 w Polsce określona została na kwotę 41985 zł, wysokość progu kosztu uzyskania dodatkowego roku życia skorygowanego o jakość wynosi $125955 \mathrm{zl}(3 \times 41985 \mathrm{zl}){ }^{\text {"4 }}$.

Powróćmy teraz do przedstawionego powyżej przypadku pacjenta chorego na raka. Jak pamiętamy, innowacyjna chemioterapia dałaby pacjentowi szansę przeżycia o pół roku dłużej, ale kosztowałaby o 100000 zł więcej od kuracji standardowej. Czy pan X ma prawo do jej refundacji?

Według obowiązujących reguł będzie to jeszcze zależeć od tego, jak wielkim pożytkiem byłby dla niego ten dodatkowy czas życia. Sam fakt, że jego spodziewane życie zwiększałoby się o pół roku, nie znaczy jeszcze, że odniósłby on dzięki temu zdrowotną korzyść o wielkości 1/2 QALY. Jak bowiem pamiętamy, 1 QALY oznacza rok życia o nieobniżonej jakości, pod-

\footnotetext{
${ }^{3}$ Dz.U. Nr 122, poz. 696 z późn. zm.

${ }^{4}$ Agencja Oceny Technologii Medycznych i Taryfikacji, „Komunikat Prezesa Agencji Oceny Technologii Medycznych i Taryfikacji w sprawie obowiązującej od dnia 4 listopada 2015 r. wysokości progu kosztu uzyskania dodatkowego roku życia skorygowanego o jakość", dostęp 25.10.2017, http://wwwold.aotm.gov.pl/index.php?id=1064
} 
czas gdy jest nader nieprawdopodobne, aby jakość dodatkowych miesięcy życia, które pan X uzyska dzięki nowej chemioterapii, nie była w żaden sposób obniżona. Przyjmijmy jednak dla prostoty, że tak właśnie będzie. Otóż nawet przy tym optymistycznym założeniu pan $\mathrm{X}$ uzyska jedynie pół roku życia skorygowanego o jakość, a zatem korzyść zdrowotną wycenianą co najwyżej na 63000 zł, za którą publiczny płatnik zapłaci 100000 zł, czyli grubo powyżej dopuszczalnego progu kosztu uzyskania. Wynik tego rachunku jest nieubłagany: nowa terapia dla pana $\mathrm{X}$-a nie kwalifikuje się do refundacji.

Ta surowa konkluzja nie harmonizuje jednak z dość powszechną i bardzo „ludzką" skłonnością, jaką jest tendencja do faworyzowania osób bliskich śmierci: wobec chorych, którym zostało już niewiele życia, w alokacji zasobów zdrowotnych przyjmuje się pewną „taryfę ulgową”. Ta praktyka jest często stosowana w sposób nieformalny, ale może być także usankcjonowana, jak to jest np. w Wielkiej Brytanii. Brytyjskim odpowiednikiem - czy raczej pierwowzorem - polskiej Agencji Oceny Technologii Medycznych — jest czuwająca nad racjonalnością publicznych wydatków na zdrowie agencja o wdzięcznym akronimie NICE. Zgodnie $\mathrm{z}$ ogólną regułą, rekomendowaną przez tę instytucję refundowane powinny być tylko takie procedury medyczne, w wypadku których koszt uzyskania jednego roku życia o nieobniżonej jakości zdrowotnej nie przekracza $£ 30000^{5}$. Od tej reguły dopuszcza się jednak wyjątki, zwłaszcza gdy chodzi o pacjentów bliskich śmierci. Wydana w 2009 r. uzupełniająca instrukcja NICE w sprawie kryteriów kwalifikacji leków stosowanych u schyłku życia (NICE 2009) rozluźnia w stosunku do tych chorych rygor $£ 30$ 000; pozwala refundować także nowe terapie, których dodatkowy koszt przekracza ten próg, o ile spełnione są trzy warunki:

2.1.1 nowa terapia jest przeznaczona dla pacjentów z krótkim przewidywanym czasem życia, normalnie nieprzekraczającym 24 miesięcy;

2.1.2 mamy podstawy sądzić, że nowa terapia wydłuży życie statystycznego pacjenta przynajmniej o 3 dalsze miesiące, w porównaniu z (najskuteczniejszą) terapią stosowaną dotychczas;

2.1.3 terapia jest przeznaczona dla niewielkiej grupy pacjentów ${ }^{6}$.

Ostatnie z przytoczonych zastrzeżeń — „dla niewielkiej grupy pacjentów" - jest uzasadnione raczej pragmatycznie: ma zapobiegać wydatkom,

\footnotetext{
${ }^{5}$ Por. RAwLins 2010. Dokładniej mówiąc, podana kwota $£ 30000$ jest górną granicą przedziału wątpliwej efektywności ekonomicznej, którego dolną granicę stanowi kwota $£ 20000$ jako koszt uzyskania jednego dodatkowego QALY.

${ }^{6}$ NICE 2009, 2.
} 
które w większej skali zrujnowałyby system opieki zdrowotnej. Wymóg drugi — „przynajmniej o 3 dalsze miesiące” — stara się zagwarantować, aby dodatkowe koszty przedłużania życia osób bliskich śmierci były choćby w jakimś stopniu wyrównywane przez korzyść tych osób. Kluczowy jednak dla nas jest warunek pierwszy: wprowadzana „ulgowa taryfa” stosuje się tylko do pacjentów, którzy bez nowej terapii, pozwalającej im przeżyć kilka miesięcy dłużej, mieliby przed sobą „normalnie” najwyżej dwa lata, a więc wyjątkowo może trochę więcej.

Te osoby, które według statystycznych prognoz umrą najpóźniej za dwadzieścia kilka miesięcy, traktuje się więc w sposób szczególny, fundując im wspaniałomyślnie coś, czego odmawia się innym. Umożliwia się im dostęp do terapii związanych $\mathrm{z}$ takim kosztem, który w innych, mniej gardłowych przypadkach - np. u chorego na cukrzycę, który bez innowacyjnej terapii umrze dopiero za 12 lat $^{7}$ - uważa się za zbyt wysoki w stosunku do dodatkowej korzyści. Krótko mówiąc, tym niemającym już przed sobą zbyt wiele czasu pacjentom przyznaje się pewien uprzywilejowany status, który — w niejakiej analogii do uznawanego w dawniejszej etyce lekarskiej „przywileju terapeutycznego" - można by nazwać przywilejem terminalnym. Jest on bowiem przyznawany osobom, które mają już przed oczyma swój terminus vitae, a więc wkraczają w pewną strefę śmierci, aczkolwiek zakreśloną nieco szerzej, niż to się czyni zazwyczaj.

Czy przywilej terminalny da się czymś usprawiedliwić? Czy jest jakiś sposób, aby usunąć wydatki na leczenie pana X-a spod nielitościwych nożyc ekonomii i mimo wszystko podarować mu — nie w irracjonalnym odruchu współczucia, ale w oparciu o jakieś racje - te dodatkowe 6 miesięcy życia, których zapewne pragnie?

Otóż istotnie można to uczynić, i to nawet na trzy różne sposoby, chociaż każdy z nich — jak zobaczymy — okaże się problematyczny. Po pierwsze, jeżeli refundacja jakiejś kosztownej terapii przedłużającej życie w wypadku pewnej osoby zbliżającej się do śmierci jest wykluczana przez zasadę efek-

\footnotetext{
${ }^{7}$ Warto tutaj przytoczyć zamieszczoną 27 maja 2014 r. w wortalu „Rynek zdrowia” wypowiedź, w której prof. Leszek Czupryniak, prezes Polskiego Towarzystwa Diabetologicznego, próbuje wyjaśnić, dlaczego osoby chore na cukrzycę nie mają w Polsce dostępu do nowych terapii: „Leczenie cukrzycy nie przynosi efektów w krótkim czasie, dlatego urzędnicy wolą koncentrować się np. na poprawie leczenia nowotworów [...]. Cukrzyca nie zabija natychmiast, a to, co się poprawia jej w leczeniu, nie przynosi efektów za pół roku, za rok, tylko po 5-10, a nawet 20 latach”. Rynekzdrowia.pl, Diabetologia, dostęp: 25.10.2017, http://www.rynekzdrowia.pl/SerwisDiabetologia/Specjalisci-koszty-refundacji-nowych-lekow-w-terapii-cukrzycy-nie-musza-bycwysokie, 141377, 1016.html.
} 
tywności, wówczas zawsze można bronić dopuszczalności tej pierwszej, zawieszając ważność drugiej. I w tym celu nie trzeba nawet posuwać się do skrajnej tezy, że w odniesieniu do pacjentów bliskich śmierci zasada efektywności traci jakąkolwiek moc obowiązującą. Wystarczy przyjąć, że w tym zastosowaniu okazuje się ona słabsza, a zatem mniej kategoryczna, od pewnej zasady konkurencyjnej. Jak bowiem wcześniej zapowiedziałem, problem właściwej dystrybucji zasobów zdrowotnych ma być tutaj rozpatrywany na gruncie pewnej minimalnej teorii konsekwencjalizmu, przyjmującej zasadę maksymalizacji dobra, a także wyprowadzoną z niej zasadę efektywności, ale nie przyznającej im zawsze „ostatniego słowa”. Ten minimalny konsekwencjalizm zna również inne ważne zasady etyczne - np. zasadę równego traktowania lub zasadę nieopuszczania w potrzebie - które mogą zderzać się z zasadą efektywności i niekiedy brać nad nią górę. Czy jednak te inne zasady etyczne dają się zastosować także w tym przypadku - a zatem użyć do uzasadnienia przywileju terminalnego - to wydaje się dosyć wątpliwe. Gdy chodzi o równe traktowanie, nie musi ono polegać na tym, że pacjentom bliskim śmierci bez względu na cenę zapewnia się równą korzyść zdrowotną — np. określoną liczbę dodatkowych miesięcy życia — jak bardziej odległym od śmierci czy też „mniej terminalnym” pacjentom, którzy mogą ją odnieść znacznie mniejszym kosztem. Co więcej, można by nawet powiedzieć, że faworyzowanie osób bliskich śmierci wręcz urąga zasadzie równego traktowania, ponieważ nie pozwala na przydzielenie ograniczonych zasobów zdrowotnych pacjentom, którzy znajdują się w równej, a czasem i w większej potrzebie, tylko dlatego, że ich potrzeba nie jest aż tak pilna. Także gdy chodzi o zasadę nieopuszczania w potrzebie, wymaga ona jedynie, aby osób skazanych na śmierć w nieodległym terminie nie pozostawiać bez jakiejkolwiek pomocy medycznej, a nie żeby wszelkimi kosztami jak najdalej odsuwać termin ich śmierci. A przecież morituri, którym odmawia się nieefektywnej terapii przedłużającej życie, nie są pozostawiani bez żadnej pomocy, jeżeli zapewnia się im troskliwą opiekę paliatywną.

Druga strategia, którą można obrać w celu obrony przywileju terminalnego, polega na pewnej próbie pogodzenia zasady efektywności z praktyką faworyzowania osób bliskich śmierci. Zarzut ekonomicznej nieefektywności stawia się terapii, w wypadku której wynikająca z niej dodatkowa korzyść jest uzyskiwana zbyt wysokim kosztem, tzn. kosztem, który mieści się już powyżej dopuszczalnego progu. Ten maksymalny próg kosztu uzyskania jednostki dodatkowej korzyści zdrowotnej, np. jednego roku życia lub jednego QALY, nie jest jednak sztywny i nienaruszalny. Chociaż jego całkowite 
zniesienie np. w wypadku osób bliskich śmierci byłoby posunięciem nieodpowiedzialnym, zawsze $\mathrm{w}$ grę wchodzi jego podniesienie. Tak zatem można by zadecydować, że chociaż przedłużanie życia osób bliskich śmierci nie może być przeprowadzane wszelkim kosztem, to jednak jego koszt, w stosunku do osiąganej korzyści, może być znacznie wyższy niż w innych przypadkach. Nie jest jednak jasne, kto właściwie miałby podjąć tego rodzaju decyzję, która czyniłaby poniekąd regułę z czegoś, co wprawdzie jest akceptowane, ale raczej jako spontaniczne i niemetodyczne odstępstwo od pewnej reguły. Nawet najbardziej irracjonalny wydatek na życie może być usprawiedliwiony jako gest współczucia. Do takich gestów są jednak powołane osoby prywatne, a nie urzędnik będący szafarzem dobra publicznego ${ }^{8}$.

Oprócz tych dwóch naszkicowanych sposobów usprawiedliwienia przywileju terminalnego jest jednak i trzeci, w aksjologicznej perspektywie tego artykułu szczególnie nas interesujący. Możemy go zarysować, jeszcze raz wracając do naszego przypadku pacjenta chorego na raka. Otóż nawet gdy potwierdzimy, że zasada efektywności obowiązuje także dla terapii przedłużającej życie osób bliskich śmierci, i podtrzymamy próg opłacalności, którego nie mogą przekroczyć koszty tej terapii, nie znaczy to jeszcze, że wydatki na niezbyt skuteczną terapię przedłużającą życie pana X-a muszą zostać koniecznie odcięte przez nieubłagane nożyce ekonomii zdrowia. Nożyce ekonomii odcinają pewne świadczenia zdrowotne, przynoszące zbyt małą korzyść w stosunku do kosztów, ale to od nas i od naszych kryteriów zależy, jak oszacujemy korzyść przynoszoną przez jakieś świadczenia danej grupie chorych. Tę samą korzyść, którą musielibyśmy uznać za zbyt małą przy zastosowaniu standardowej metody oceny, możemy ocenić jako dostateczną, stosując metodę zmodyfikowaną. Tak więc możemy zadecydować, że pewna liczba miesięcy życia, podarowanych tym, którzy przechodzą już do strefy śmierci, w naszym rachunku korzyści nie będzie liczyć się tak samo, jak równa liczba także jakościowo podobnych miesięcy dodanych do życia tych, dla których perspektywa śmierci jest jeszcze odległa. Jeżeli np. przyjmiemy, że w wypadku zbliżających się już do śmierci pacjentów ich zdrowotne korzyści liczą się podwójnie, wówczas chory na raka pacjent z naszego przykładu, według standardowych kryteriów uzyskujący tylko pół

\footnotetext{
${ }^{8}$ Zgodnie z tym DIXON i in. (2009) stoją na stanowisku, że cytowana wyżej instrukcja NICE w sprawie bardziej „,wspaniałomyślnej” refundacji leków dla pacjentów u schyłku życia, wbrew nasuwającej się interpretacji, nie podnosi specjalnie dla tych chorych progu dopuszczalnej kosztowności osiąganych korzyści zdrowotnych, lecz raczej sugeruje, aby osiąganym w tym wypadku korzyściom przyznać większą wagę.
} 
roku życia, według kryteriów uzupełnionych, mianowicie wzbogaconych o pozycję ze względu na przyszłość, uzyskiwałby już cały rok życia skorygowanego o wartość. A tak oceniana korzyść będzie już wystarczająca, aby wydatek na jego terapię zmieścił się jeszcze pod progiem dopuszczalnego kosztu uzyskania jednego roku życia o pełnej wartości.

Trzecią możliwą strategią obrony przywileju terminalnego będzie zatem ta, która ani nie ogranicza ważności zasady korzyści i kosztów, ani nie podnosi progu dopuszczalnych względnych kosztów dla terapii przedłużających życie bliskie śmierci, lecz odwołuje się do tezy o rosnącej wartości, jaką należy przyznać temu życiu.

Przyjrzyjmy się nieco uważniej tej trzeciej koncepcji, która dopuszcza jeszcze rozmaite wersje.

Jeżeli wartość ludzkiego życia rozumiana jest jako wartość dla kogoś, tzn. jako wartość relacjonalna czy też posiadająca pewien osobowy punkt odniesienia, wówczas wartość pewnego dodatkowego odcinka życia osoby zbliżającej się do śmierci może być rozumiana w co najmniej trojaki sposób, a mianowicie jako wartość dla niej samej, jako wartość dla jej bliskich lub jako wartość dla społeczeństwa9 .

Wyjdźmy od wartości, którą dłuższe życie osoby bliskiej śmierci może mieć dla jej bliskich. Jeden z odwołujących się do niej autorów (CHOCHINOV 2011) radzi nam przeprowadzić pewien eksperyment myślowy. Mamy sobie wyobrazić, że siedzimy - lub też przypomnieć sobie, jak siedzieliśmy — u wezgłowia umierającej kochanej osoby. I możemy sami siebie zapytać, ile dalibyśmy za to, aby — nie narażając jej na dodatkowe cierpienie — móc przedłużyć jej życie o miesiąc, o tydzień, lub choćby o dzień. Chociaż na takie pytanie trudno udzielić określonej odpowiedzi, to jednak ten eksperyment uświadamia nam, zdaniem autora, że dodatkowy czas życia zyskuje inną wartość wobec bliskiej śmierci.

Cookson (2013) krytykuje jednak tę argumentację z wartości dla innych,

\footnotetext{
${ }^{9}$ Dwa ostatnie rozumienia wartości osobowego życia można też z sobą łączyć. Czynią to np. BECKER i in. (2007), gdy zauważają, że „społeczna wartość” życia pewnej osoby jest często większa niż jego wartość prywatna. Jeżeli zatem przedłużenie życia danej osoby pociąga za sobą pozytywne skutki dla innych — „członków rodziny, altruistycznych podatników, czy też członków grup interesu, czerpiących korzyści z publicznej opieki zdrowotnej” — wówczas może być uzasadnione przeznaczenie na ten cel kosztów wyższych niż te, które byłyby optymalne, gdyby uwzględniać jedynie prywatną wartość większej długości życia poszczególnych pacjentów.
} 
a szczególnie z wartości, którą dłuższe życie śmiertelnie chorej osoby ma dla jej zatroskanych bliskich, wysuwając przeciwko niej trzy zarzuty: (1) argument wartości dla zatroskanych bliskich jest argumentem obosiecznym, ponieważ taką społeczną wartość mają także inne korzyści zdrowotne, które trzeba ograniczyć, skupiając się na korzyściach osób bliskich śmierci; (2) argument ten może prowadzić do dyskryminacji chorych, którzy nie miały nikogo bliskiego lub którym nie pozostał już nikt, kto by się o nich troszczył; (3) zasoby opieki zdrowotnej powinne być rozdzielane stosownie do potrzeb, a nie w proporcji do takich czy innych korzyści, które ich beneficjenci przynoszą najbliższemu otoczeniu lub też społeczeństwu.

Szczególna wartość życia osób bliskich śmierci, uzasadniająca również większą ważność, jaką przypisuje się przedłużaniu ich życia, może być także interpretowana jako wartość dla szerzej pojmowanego społeczeństwa czy też wartość symboliczna. Jak zauważali różni autorzy (por. np. CHOCHINOV 2011), otaczanie szczególną troską osób umierających zwiększa poczucie bezpieczeństwa innych osób - pozwala im liczyć na to, że również one będą traktowane w ten szczególny sposób, gdy wybije ich godzina. Po tym, jak traktujemy naszych umierających, można również poznać, kim jesteśmy jako społeczeństwo. Bezwzględne oszczędzanie na umierających miałoby „mrożący wpływ na naszą zbiorową jakość życia”, podważając naszą wiarę, że żyjemy w społeczeństwie moralnym i sprawiedliwym.

Cookson (2013) odpiera jednak również ten argument $\mathrm{z}$ wartości dla społeczeństwa lub wartości symbolicznej, jaką można przypisywać nieszczędzeniu środków na przedłużanie życia osób bliskich śmierci. Instytucje społeczne - jak zauważa — już i bez tego angażują się w szereg poczynań, które symbolizują szczególną wargę przykładaną przez społeczeństwo do ludzkiego życia - działania medycyny ratunkowej, w których przyznaje się pierwszeństwo osobom zagrożonym śmiercią, regulacje mające zapewniać bezpieczeństwo publiczne itp. Chodzi więc nie o to, czy akty symbolizujące wartość ludzkiego życia są w ogóle potrzebne; jest raczej do dyskusji, czy te szczególne akty symboliczne, jakimi są nieograniczone wydatki na umierających, wnoszą coś istotnie nowego i dają się usprawiedliwić wobec związanych z nim kosztów, ponoszonych przez innych chorych.

Najbardziej naturalnym rozumieniem wartości dodatkowych miesięcy lub tygodni życia, podarowanych człowiekowi zbliżającemu się do śmierci, wydaje się wszakże to, w którym stanowi ona przede wszystkim wartość dla samego obdarowanego. Pytając, czy wartość życia wzrasta wobec bliskiej śmierci, staralibyśmy się wówczas ustalić, czy dodatkowe miesiące życia 
pozyskiwane przez osobę zbliżającą się do śmierci mają dla niej samej większą wartość jedynie dlatego, że lata jej dalszego życia są już „policzone". I w tym jednak rozumieniu rozważane przez nas pytanie nie jest jeszcze jednoznaczne, ponieważ owa rosnąca wartość, którą przybiera życie człowieka bliskiego śmierci, ze względu na jej naturę lub podstawę może być jeszcze klasyfikowana bądź to jako wartość wewnętrzna, bądź jako pewna wartość zewnętrzna, mianowicie instrumentalna (wynikająca z jego przydatności do jakiegoś innego celu) lub kontrybucyjna (wynikająca $\mathrm{z}$ wkładu, jaki końcowa część życia wnosi do jego całości).

Jako wartość instrumentalną traktują ją ci, którzy wskazują, że osoba bliższa śmierci ma mniej czasu, aby zrealizować swoje zaległe projekty czy niespełnione zamysły życiowe. Im mniej jednak posiada się jakiegoś cennego dobra, tym staje się ono cenniejsze. Darowany czas życia jest cenny jako materiał, z którego można jeszcze zrobić coś wartościowego. Osoba otrzymująca dodatkowy czas życia może go wykorzystać do tego, aby pozałatwiać różne dotąd niepozałatwiane sprawy: doprowadzić do końca niezakończone projekty, pożegnać się z przyjaciółmi, pogodzić się z dawnymi wrogami itd.

Jak jednak wskazuje Cookson, również w tym argumencie „z czasu potrzebnego na uporządkowanie swoich spraw" (czy — jak brutalniej mówią inni — „na posprzątanie po sobie”) daje się zauważyć kilka słabych punktów. Po pierwsze, korzyści z tych „pożegnalych działań” osób bliskich śmierci odnoszą często ich bliscy, a nie one same. Po drugie, argument „czasu potrzebnego do zamknięcia życia” stosuje się w najlepszym razie tylko do niektórych pacjentów, spełniających kryteria sformułowane przez NICE. Nie daje się mianowicie zastosować do tych, u których śmiertelną chorobę zdiagnozowano już wcześniej, tak że mieli oni dość czasu, aby zrobić porządek w swym życiu. Po trzecie, na „doprowadzenie do porządku swoich spraw" osoba bliska śmierci potrzebuje zwykle nie tyle więcej czasu, ile czasu o wyższej jakości; tak więc od terapii przedłużającej życie bardziej może jej w tym pomóc stosowna opieka paliatywna.

Jako innego typu wartość zewnętrzna, a mianowicie wartość kontrybucyjna (contributory value) wartość dodatkowego czasu życia dla osoby bliskiej śmierci jest interpretowana przez tych, który wiążą ją z wkładem, jaki końcowa część życia wnosi do jego całości. Tak np. Dworkin (1993, 199) porównuje ostatnią fazę życia do końcowej sceny w tragedii lub ostatniej zwrotki w poemacie, na których znaczenie składa się nie tylko ich wewnętrzna treść, lecz także ich wpływ na całość utworu. Podobnie Hughes 
(2005) argumentuje, że aby uniknąć drastycznych cięć i ograniczeń wymuszanych w opiece zdrowotnej przez standardową metodę „analizy kosztów i korzyści”, zwolennicy zwiększonych nakładów na opiekę u schyłku życia muszą porzucić atomistyczne podejście do wartości życia i zastąpić je ujęciem holistycznym.

Najbardziej kuszącą interpretacją wartości dłuższego życia, darowanego osobie zbliżającej się do śmierci, jest jednak z pewnością ta, która ujmuje ją jako wartość wewnętrzną. Choć można się zastanawiać, czy wewnętrzna wartość życia osób bliskich śmierci jest ceteris paribus obiektywnie większa, nie ulega wątpliwości, że jest ona przez te osoby niejednokrotnie wyżej oceniana.

Becker $\mathrm{i}$ in. (2007) podają przynajmniej trzy główne powody wyższej oceny wartości własnego życia wobec bliskiej śmierci ${ }^{10}$.

1. „Koszty alternatywne” (czy też polegające na utracie alternatywnych korzyści — opportunity costs) terapii przedłużającej życie są niskie, ponieważ zagrożeni bliską śmiercią pacjenci nie przywiązują wagi do dóbr materialnych, które pozostaną po nich po śmierci.

2. Ważnym, a często pomijanym uzasadnieniem większych nakładów na opiekę u schyłku życia jest podtrzymanie nadziei, będącej jak gdyby obecną radością z życia spodziewanego w przyszłości (the current consumption of future survival).

3. Niższa jakość życia nie obniża oceny jego wartości, gdy pewna osoba nie może zachować życia o wyższej jakości. (Jeżeli pacjent chory na raka krtani zamieniłby trzy lata życia bez zdolności mówienia na dwa lata życia w chorobie, ale ze zdolnością mówienia lub na rok życia w zdrowiu, wówczas można powiedzieć, że jakość życia bez bez zdolności mówienia ocenia on na $1 / 3$, a jakość życia życia w chorobie, ale ze zdolnością mówienia na $2 / 3$. Stąd jednak nie wynika, że także w sytuacji, gdy musi się on zdecydować na laryngoktomię, aby w ogóle zachować życie, ocecnia on wartość tego dalszego życia jako równa $1 / 3$ wartości życia zdrowego.)

Menzel (2011) do trzech wymienionych (i potwierdzanych także przez niego) przyczyn wyższej oceny dłuższego życia u osób bliskich śmierci dodaje jeszcze jedną, którą jest zmiana punktu odniesienia (shifting reference points). Spostrzegana wartość pewnego dobra zależy od punktu odniesienia, jaki przyjmuje się w jego ocenie. Ocena wartości życia jest za-

\footnotetext{
${ }^{10}$ Czwartym wymienianym przez nich powodem jest wzgląd na wyższą społeczną wartość życia bliskiego śmierci; jak jednak zauważają sami autorzy, nie dotyczy on tej wartości, którą dodatkowe miesiące życia pacjenta zbliżającego się do śmierci posiadają dla niego samego.
} 
leżna od punktu odniesienia pod dwoma względami. Po pierwsze, ma na nią wpływ proporcja, jaka zachodzi między dodatkowym czasem życia, uzyskiwanym dzięki pewnej terapii, a czasem życia spodziewanym i bez tej terapii: dodatkowe sześć miesięcy życia, które dojdą do sześciu już spodziewanych miesięcy, ocenia się inaczej niż takie same sześć miesięcy, które uzyska się w dodatku do dziesięciu lat. Drugim czynnikiem, który wpływa na ocenę życia i wiąże się z jej punktem odniesienia, jest odległość czasowa: sześć miesięcy życia, które uzyska się już po dwu latach, wydaje się cenniejsze niż sześć miesięcy życia, uzyskiwane dopiero po dziesięciu latach.

Zreferowanym uwagom trudno odmówić trafności. Wyjaśniają one jednak tylko powody, dla których osoby zbliżające się do śmierci bardziej sobie cenią podarowane im miesiące lub tygodnie życia; nie dowodzą zatem, że ten dodatkowy czas życia ma dla nich rzeczywiście także większą wartość. Ktoś mógłby wprawdzie stwierdzić, że rozróżnienie subiektywnej oceny, którą pewna osoba wydaje na temat darowanego jej czasu życia, a rzeczywistej wartości, którą ten dodatkowy czas ma dla owej osoby, jest w tym wypadku zbędne czy też nieuzasadnione. Tak np. Menzel retorycznie pyta: „Dopóki przyznajemy, że wartość przypisywana życiu jest wartością subiektywną - ostatecznie więc wartością przysługującą istotom ludzkim z subiektywną świadomością — czemu mielibyśmy lekceważyć [zmiany jej oceny] powodowane przez zmieniający się punkt odniesienia jako coś irracjonalnego lub niedorzecznego?" (MENZEL 2011, 217). Lecz nawet jeśli zgodzić się z tym stanowiskiem - a zatem przyznać, że subiektywna czy też osobista wartość życia wręcz dramatycznie wzrasta wobec bliskiej śmierci - to i tak pozostaje jeszcze wątpliwość, czy to samo da się stwierdzić o jego wartości intersubiektywnej lub też neutralnej ${ }^{11}$, a więc o tej jego wartości, od której powinny być uzależniane decyzje w sprawie alokacji zasobów i finansowaniu świadczeń opieki zdrowotnej.

Przedstawiając swoją koncepcję ,racji względnych w stosunku do podmiotu", czyli nie neutralnych, Thomas Nagel zalicza do nich między innymi „racje autonomii”. Aby zilustrować tę grupę racji czy też wartości, pisze, że ktoś może chcieć zdobyć szczyt Kilimandżaro lub zostać pianistą, ale to nie znaczy, że inni mają powód pomagać mu w zrealizowaniu tych celów (por. NAGEL 1997, 204). W ten sposób autor Widoku znikąd sugeruje, że zdobycie szczytu Kilimandżaro przez X-a może być czymś dobrym z punktu widzenia

\footnotetext{
${ }^{11} \mathrm{~W}$ sprawie rozrożnienia wartości osobistej (lub relacjonalnej) i wartości neutralnej por. GALEWICZ 2016.
} 
$\mathrm{X}$-a, chociaż nie czymś dobrym dla świata. Nasuwa się myśl, że podobnie jak ze zdobyciem szczytu Kilimandżaro, na przekór zmęczeniu, może być z przeżyciem przez jaką́s osobę dodatkowych trzech czy czterech miesięcy, pomimo śmiertelnej choroby. Także to dokonanie może być czymś pożądanym dla owej osoby, lecz niekoniecznie czymś równie cennym dla społeczeństwa, które musiałoby jej pomóc w zrealizowaniu tego celu, odmawiając innym osobom - chorym czy też zdrowym — środków na realizację ich życiowych planów, z neutralnego punktu widzenia być może ważniejszych.

\section{REFERENCJE}

Becker, Gary, Kevin Murphy i Tomas Philipson. 2007. „The Value of Life Near Its End and Terminal Care". NBER Working Paper No. 13333, National Bureau of Economic Research, August 2007. DOI: 10.3386/w13333.

BRADLEY, Ben. 2006. „Two Concepts of Intrinsic Value”. Ethical Theory and Moral Practice, 9: 111-130. DOI: 10.1007/s10677-006-9009-7.

Chochinov, Harvey Max. 2011. „Death, time and the theory of relativity”. Journal of Pain and Symptom Management 42, 460-463.

COOKSON, Richard. 2013. „Can the NICE 'end-of-life premium' be given a coherent ethical justification?". Journal of Health Politics, Policy and Law, 38, No. 6: 1129-48. DOI: 10. 1215/ 03616878-2373166.

Dixon, Simon, Louise LONGWORTh i Allan Wailoo. 2009. „Assessing technologies at the end of life: a review of empirical evidence. Report by the decision support unit”, 26 November 2009. NICE Decision Support Unit. Dostęp 25.10.2017. http://scharr.dept.shef.ac.uk/nicedsu/wp-content/ uploads/sites/7/2016/03/ DSU-EOL-lit-review. FINAL_.pdf.

Dworkin, Ronald. 1993, Life's Dominion: An Argument About Abortion, Euthanasia, and Individual Freedom, New York: Random House.

Galewicz, Włodzimierz. 2016. „Dobro dla kogoś i dobro dla świata”. Przegląd Filozoficzny Nowa Seria 25, nr 1 (97): 33-44.

Hughes, Jonathan. 2005. „Palliative care and the QALY problem”. Health Care Analysis 13, 289-301. DOI: 10.1007/s10728-005-8126-0.

Menzel, Paul T. 2011. „The Value of Life at the End of Life: A Critical Assessment of Hope and Other Factors". Journal of Law, Medicine and Ethics 39, no. 2: 215-23. DOI: 10.1111/j.1748720X.2011.00590.x.

NAGEL, Thomas. 1997. Widok znikad. Tłum. Cezary Cieśliński. Warszawa: Fundacja „Aletheia”.

NICE [National Institute for Health and Clinical Excellence]. 2009. Appraising Life-Extending, End of Life Treatments. London: National Institute for Health and Clinical Excellence.

Rawlins, Michael, David Barnett i Andrew Stevens. 2010. „Pharmacoeconomics: NICE's approach to decision-making”. British Journal of Clinical Pharmacology, 70(3): 346-349. DOI: $10.1111 / \mathrm{j} .1365-2125.2009 .03589 . x$. 


\section{CZY WARTOŚĆ ŻYCIA WZRASTA WOBEC BLISKIEJ ŚMIERCI?}

\section{Streszczenie}

Przemysł farmaceutyczny oferuje coraz to nowe leki, które mają przedłużać życie osób cierpiących na nieuleczalne choroby. Innowacyjne terapie są często w jakimś stopniu skuteczniejsze, ale też (w co najmniej takim samym stopniu) droższe. Upoważnieni decydenci reprezentujący społeczeństwo muszą zatem rozstrzygać, które z nich będą finansowane ze środków publicznych. Jednym z głównych kryteriów, na których podstawie podejmuje się takie decyzje, jest stosunek dodatkowych kosztów, związanych z nową terapią, do czerpanych z niej dodatkowych korzyści. Dodatkowe korzyści, wynikające z nowych leków dla osób śmiertelnie chorych, wydają się jednak często niezbyt wielkie w porównaniu do ich zawrotnych dodatkowych kosztów. Rodzi się zatem wątpliwość, czy refundacja tych leków, do której opinia społeczna skądinąd na ogół się skłania, daje się pogodzić z równie powszechnie akceptowaną zasadą ekonomicznej efektywności. Pewną próbą uzgodnienia tych postaw byłoby przyjęcie, że z pozoru niewielkie korzyści, przysparzane osobom zbliżającym się do śmierci — jak marginalne zwiększenie długości ich życia lub nieznaczne podniesienie jego jakości — w rzeczywistości mają większą wartość, ponieważ życie tych osób trzeba cenić wyżej. W przedstawianym artykule zastanawiam się nad tym, czy ta koncepcja jest do utrzymania — czy wartość życia wzrasta wobec bliskiej śmierci.

\section{DOES THE VALUE OF LIFE INCREASE NEAR ITS END?}

\section{S u m m a r y}

The costs of life-extending care at the end of life are often disproportionately high in relation to the benefits it brings to the patients. Thus, the unrestricted principle of cost-effectiveness as a rule of rational healthcare allocation would require us to limit publicly funded life-prolonging treatments for patients nearing the end of life. From a societal perspective, however, this limitation would be often callous and inhuman. There are three possible ways to reconcile these two attitudes. First, we could restrict the principle of cost-effectiveness by questioning its validity in the field of endof-life care. Second, we could raise the acceptable upper cost-effectiveness threshold for end-oflife treatments. Thirdly, it is also possible to maintain that the seemingly rather poor effects of end-of-life treatments are actually much better, because the value of life increases as death draws near. In this paper, I discuss the plausiblity of this last solution.

Słowa kluczowe: wartość życia; opieka terminalna; terapia przedłużająca życie; alokacja zasobów zdrowotnych; efektywność ekonomiczna.

Key words: value of life; end-of-life care; healthcare allocation; cost-effectiveness.

Information about Author: Prof. Dr. hab. WŁodzimierz GALEwicz-Head of the Department for Research on Professional Ethics, Jagiellonian University in Cracow, Faculty of Philosophy, Institute of Philosophy; address for correspondence: ul. Grodzka 52, PL 31-044 Kraków; e-mail: galewicz@if.uj.edu.pl 